\title{
Limited effects of non-native trout on microcrustacean zooplankton in boreal foothills lakes: comparisons of stocked, unstocked, and fishless lakes
}

\begin{tabular}{|r|l|}
\hline Journal: & Canadian Journal of Fisheries and Aquatic Sciences \\
\hline Manuscript ID & cjfas-2015-0495.R1 \\
\hline Manuscript Type: & Article \\
\hline Date Submitted by the Author: & 30 -Jun-2016 \\
\hline Complete List of Authors: & $\begin{array}{l}\text { Holmes, Teslin; University of Alberta, Biological SCiences } \\
\text { Tonn, William; University of Alberta, } \\
\text { Paszkowski, Cynthia A.; University of Alberta, Biological Sciences; } \\
\text { Scrimgeour, Garry; University of Alberta, Biological SCiences }\end{array}$ \\
\hline Keyword: & $\begin{array}{l}\text { LAKES < Environment/Habitat, TROUT < Organisms, microcrustacea, } \\
\text { Chaoborus, stocking }\end{array}$ \\
\hline
\end{tabular}


1 Limited effects of non-native trout on microcrustacean zooplankton in boreal foothills

2 lakes: comparisons of stocked, unstocked, and fishless lakes

3

4 Teslin G. Holmes · William M. Tonn* · Cynthia A. Paszkowski · Garry J. Scrimgeour 5

6

7 T.G. Holmes · W.M. Tonn · C.A. Paszkowski · G.J. Scrimgeour

8 Department of Biological Sciences, University of Alberta, Edmonton, AB T6G 2E9, Canada

9

10 T.G. Holmes

11 e-mail: teslin@ualberta.ca

12 W. M Tonn*

13 e-mail: bill.tonn@ualberta.ca

14 C.A. Paszkowski

15 e-mail: cindy.paszkowski@ualberta.ca

16 G.J. Scrimgeour

17 e-mail: garry.scrimgeour@ualberta.ca

18

19 * Corresponding author. Tel.: 1780492 4162; Fax 17804929234 
20 Abstract

21 Stocking lakes with trout can have strong effects on native communities, however, the nature of

22 impacts is not universal across receiving ecosystems. To assess effects of non-native trout,

23 relative to native small-bodied fish, on microcrustacean zooplankton we compared stocked,

24 unstocked (but fish-bearing), and fishless lakes in the boreal foothills of Alberta, Canada.

25 Relative to unstocked lakes, stocked lakes had greater richness, but otherwise showed few

26 additional effects on microcrustacean communities. In contrast, fishless lakes supported lower

27 abundances of Cladocera, Calanoida, and Cyclopoida, but were dominated by larger cladoceran

28 and calanoid taxa, compared to fish-bearing lakes (stocked and unstocked). Vertical distributions

29 also differed significantly between lake types; microcrustaceans had far higher relative

30 abundances at $1 \mathrm{~m}$ than at $2 \mathrm{~m}$ in fishless lakes compared to fish-bearing lakes (distributions in

31 stocked and unstocked lakes were similar). Microcrustacean communities in fishless lakes were

32 likely shaped by the invertebrate planktivore, Chaoborus, which was abundant in these systems,

33 whereas native fishes likely structured microcrustacean communities prior to trout introductions,

34 with planktivory by trout causing few additional effects. 


\section{Introduction}

Sport fish stocking is employed throughout North America to create and/or enhance angling opportunities. Many species used for this purpose belong to the family Salmonidae, such as Rainbow Trout (Oncorhynchus mykiss), Brown Trout (Salmo trutta), and Brook Trout (Salvelinus fontinalis). The introduction of non-native trout, however, can alter populations of a variety of native taxa, including native small-bodied fish (e.g., Townsend 1996; Jellyman and microcrustacean taxa (Jeppesen et al. 1997, 2000; Parker et al. 2001; Tiberti et al. 2014). In McIntosh 2010), macroinvertebrates (e.g., Bradford et al. 1998; Herbst et al. 2009; MartinezSanz et al. 2010), and amphibians (e.g., Bradford et al. 1998; Mathews et al. 2001; Welsh et al. 2006). Trout can have especially strong effects on microcrustacean communities (Bradford et al. 1998; Budy et al. 2005). Stocking mountain lakes in North America and elsewhere with Rainbow, Brown, and/or Brook trout has decreased the abundance and mean body size of many cases, common large-bodied species become rare or absent in stocked lakes (Bradford et al. 1998). Stocked trout have also been found to influence the distribution of zooplankton in a manner similar to other visually foraging vertebrate planktivores (Hembre and Megard 2003). The most pronounced effects of trout stocking have been documented in unproductive and naturally fishless mountain lakes, where native communities evolved in the absence of fish (reviewed by Dunham et al. 2004). Many stocked lakes, however, are located in more productive, lower elevation ecoregions and in systems with native fish populations, but these remain relatively understudied. Potential effects of trout in such systems can be difficult to predict due to the varying responses of different local taxa and differences in habitat characteristics across ecosystems (Dunham et al. 2004; Amsinck et al. 2006; Schank et al. 2011). Freshwater systems in these areas often have higher productivity, limited water clarity, and greater species diversity than mountain systems and their (often more dense) populations of native taxa may respond to stocked trout differently (Wissinger et al. 2006; Pink et al. 2007; Schilling et al. 2009a). 
For microcrustacean communities, the presence of native fish could also limit impacts of trout, as planktivory by native fishes can be similarly size- and taxa-selective (Naud and Magnan 1988; Laurich et al. 2003), so few additional effects might be expected after stocking trout in naturally fish-bearing systems. At lower elevations, shared characteristics of microcrustacean communities in stocked and unstocked lakes containing native planktivorous fishes are expected to contrast with characteristics of communities in naturally fishless lakes, where high densities of macroinvertebrate predators may have different effects on zooplankton communities than fish (Von Ende 1979; Elser et al. 1990). In addition, a competitive dominance of large taxa can shape microcrustacean communities in the absence of fish.

Relative to neighboring Canadian provinces, Alberta has a paucity of lakes supporting game fish; combined with a large population of anglers, this translates into more than two orders of magnitude more anglers per fishing lake (Sullivan 2003). This high angling pressure has contributed to the decline of many native gamefish populations (Post et al. 2002) and consequently, an active fish-stocking program. Although a majority of the gamefish raised in Alberta fish hatcheries are native species, ca. 300 non-alpine lakes and ponds are stocked annually or biennially (some since the 1950s) with non-native trout to create additional angling opportunities that can help alleviate angling pressure on native populations (ASRD 2010, Zwickel 2012). These stocked lakes lack native gamefish, but many contain native non-game species. Only recently have studies started to examine effects of stocked trout in these systems.

Initial studies compared stocked with unstocked lakes, detecting weak effects of trout on density of native fish (Nasmith et al. 2010), composition and size structure of macroinvertebrates (Nasmith et al. 2012; Hanisch et al. 2013), and amphibian abundance (Schank et al. 2011). The latter two results were attributed, in part, to the presence of native fishes in the stocked lakes, which likely "pre-structured" resident populations prior to trout introductions. These resident vertebrates and invertebrates are primarily littoral, and may also have benefitted from the 
presence of dense macrophyte beds than can serve as refuge habitat. Does "pre-structuring" by native fishes also limit the impacts of stocked trout on zooplankton offshore in more open-water habitats?

To examine effects that introduced trout may have on microcrustacean zooplankton, relative to those of native fishes, in lakes of the boreal foothills region of Alberta, we compared communities in a set of stocked and unstocked (but fish-bearing) lakes; to put any similarities or differences into a broader ecological context, we also characterized the microcrustacean zooplankton in a smaller set of nearby fishless lakes. Given that similar selectivity for larger and/or slower zooplankton by trout and native fishes is frequently observed (Hambright and Hall, 1992; Laurich et al., 2003; Budy et al., 2005), we expected generally similar communities (taxa, body sizes) in both stocked and unstocked lakes but relatively different microcrustacean communities in fishless systems. We also predicted that differences between fishless and fishbearing (native and/or stocked) systems (i.e., fewer, but larger zooplankton in fishless vs. fishbearing lakes) would increase as the summer progressed, after trout are stocked, young-of-year native fish begin foraging, and predation by late-instar Chaoborus in fishless systems increases (von Ende 1982). As well, because large-bodied microcrustacea can outcompete smaller taxa in the absence of size-selective vertebrate predators (Brooks and Dodson 1965), fish may mediate the coexistence of species (Paine 1966), resulting in greater species richness in fish-bearing compared to fishless lakes. We also predicted that the epilimnetic vertical distribution of zooplankton in fishless ecosystems would contrast with the pattern seen in fish-bearing lakes, but distributions in both stocked and unstocked (but fish-bearing) lakes would be similar. Finally, as study lakes were broadly comparable limnologically, we expected that the presence or absence of fish (stocked and native) would be more important in structuring microcrustacean communities than would environmental variables.

\section{Methods}

Study Area and Study Lakes 
Study lakes $(\mathrm{n}=14)$ in the boreal foothills near Rocky Mountain House (52²2’39’'N and $114^{\circ} 54^{\prime} 37^{\prime \prime} \mathrm{W}$ ) and Caroline (52 5'36' $\mathrm{N}$ and $\left.114^{\circ} 45^{\prime} 28^{\prime \prime} \mathrm{W}\right)$, Alberta were sampled monthly

115 (May- August 2009). Lakes were relatively small (1-31 ha) and shallow (2-13 m), and typically

116 surrounded by forest. Many shorelines supported thick patches of Typha latifolia, while littoral

117 zones were generally characterized by dense macrophytes (Potamogeton spp., Sparganium

118 angustifolium, and Nuphar variegatum; Nasmith et al. 2010).

Lakes were either fishless $(n=3)$, unstocked $(n=5)$ or stocked with trout $(n=6$; primarily

120

121

122

123

124

125

126

127

128

129

130

131

132

133

134

135

136

137

138

139

Rainbow, > $245 \mathrm{~mm}$ fork length; Table 1). Stocking typically occurs in spring and is repeated

annually or biannually, as trout do not reproduce in these lakes (S. Herman and R. Konynenbelt, Alberta Fish and Wildlife, personal communication). Stocked and unstocked lakes both supported populations of native small-bodied fishes (Table 1). Although unstocked lakes were chosen from a list of regional lakes under consideration for future stocking by Alberta Fish and Wildlife, and preliminary visits to the lakes confirmed their general similarity to stocked lakes (C. Paszkowski, G. Scrimgeour, and W. Tonn, personal observations), fish managers do not select lakes randomly for stocking; stocked lakes tend to be somewhat larger, deeper, and less productive to reduce potential for winterkill (see also Pope 2008).

Epilimnetic water samples were collected at the deepest location within each lake. Using standard methods, samples were analysed for total nitrogen (TN), total dissolved nitrogen (TDN), total phosphorous (TP), total dissolved phosphorous (TDP), and chlorophyll-a (Chl- $a$ ) at the University of Alberta's Biogeochemical Analytical Laboratory (Edmonton, Alberta). Full temperature and dissolved oxygen (DO) profiles were also taken at the end of each month (MayAugust) at $1 \mathrm{~m}$ intervals, in addition to Secchi transparency and epilimnetic measures of $\mathrm{pH}$ and conductivity.

Microcrustacean Collection and Laboratory Processing Pelagic microcrustaceans were collected in daylight during 5-d periods in each month (May- August 2009). Samples were collected at 1-m intervals from the deepest location in each 
140 lake using a 30-L, 63- $\mu \mathrm{m}$ mesh Schindler-Patalas trap and preserved in $80 \%$ ethanol until 141 laboratory processing. For May, June, and August, samples from each metre were combined to 142 produce a single composite sample for each lake, whereas samples from each depth were processed separately for July to examine vertical distribution (Holmes 2012). Microcrustaceans were counted and identified to the lowest feasible taxonomic level (LFTL; generally species, however, family was used for Chydoridae); identifications were based on Edmondson (1959). In the case of damaged individuals, only fragments with a head were counted. Samples were sub-sampled using a $1 \mathrm{~mL}$ Hensen-Stempel pipette until at least 250 individuals were counted, with a maximum of 50 individual from each LFTL contributing to the total (see Christensen et al. 2006). Larvae of Chaoborus, the only macroinvertebrate caught consistently in the plankton trap, were also counted and identified to species for July. measured using a calibrated ocular micrometer. Measurements were dorsal lengths, excluding appendages/projections, on straightened individuals. With these measurements, we calculated "taxon length" for Calanoida, Cyclopoida, and Cladocera for each sample by determining the mean length of each LFTL within an order and then taking the average of those mean lengths. Lengths of each LFTL were also used to convert abundances into biomass (McCauley 1984; Culver et al. (1985).

Statistical Analyses

Univariate analyses were conducted using SPSS for Mac OS X (Rel. 19.0.0 2010). A Komolgorov-Smirnov test assessed normality for each data set and Levene's test assessed the homogeneity of variance. Data that were not normally distributed were $\log 10(\mathrm{x}+1)$ transformed. Results were considered significant if $\mathrm{p}<0.05$, and marginally significant if $0.05<\mathrm{p}<0.1$.

Linear Mixed Models (LMM) assessed differences in abundance, biomass, and mean taxon length of Cladocera, Calanoida, and Cyclopoida, and total taxon richness among the three 166 lake types and the four sampling periods, using lake type, month, and their interaction as fixed 
167 variables and lake as a random variable (SPSS Inc. 2010). Juvenile cladocerans and copepod 168 copepodites were grouped with adults, but because copepod nauplii could not be classified, they 169 were removed from LMMs. Due to insufficient sample sizes ( $<15$ lengths/lake/sample period), 170 length analyses excluded cladocerans in May, and calanoids and cyclopoids in May and June.

171 For these and all other LMMs, if the interaction term was not significant ( $\mathrm{p}>0.05)$, it was

172 subsequently removed from the analysis. After lake type was found to have a significant effect

173 on taxonomic richness, we examined richness - lake area and richness - depth relations using

174 linear regression to assess the potential for increases in richness with greater morphometric 175 complexity (Tessier and Welser 1991). We also assessed differences in Chaoborus abundance 176 among lake types in July using a one-way Analysis of Variance (ANOVA). types, we applied Nonmetric Multidimensional Scaling (NMS) ordinations using Sorensen (Bray-Curtis) distance measure to LFTL presence/absence data. Ordinations were conducted separately for each sampling period, and for all lake-months combined; for the latter analysis, lake type-month centroids were plotted to illustrate the succession of microcrustacean communities through time. Ordinations were performed using the "slow and thorough" method of PC-ORD version 6.0 (McCune and Mefford 2011). Rare taxa (occurring in $<3$ lakes) were deleted or merged to form a larger taxonomic group. When three or more axes were recommended, the two axes that represented the most variation were plotted for visual assessment. Biplots of important taxa $\left(\mathrm{r}^{2}>0.5\right)$ and environmental variables $\left(\mathrm{r}^{2}>0.3\right)$ were plotted to examine relationships with the ordination axes.

To test for compositional differences among the three lake types, we performed Multiple Response Permutation Procedures (MRPP; McCune and Grace 2002) on LFTL presence/absence data. MRPPs were also performed on environmental data. Area and depth, selected to be greater by fish managers for stocked lakes, were removed from the final analyses to see if environments differed among lake types based on the remaining variables. All MRPPs were done separately for each month. 

compare similarities between the two matrices. Fish taxa included were "trout", Fathead Minnow, Brook Stickleback, dace species complex, and a "fishless" category. Mantel Tests were also performed on microcrustacean and environmental data. Area and maximum depth were again removed from the analysis to assess relationships with the remaining environmental variables. All Mantel tests were done separately for each sampling period. was used to assess the proportion of variance in the composition of microcrustacean communities that could be explained by the environmental variables and the fish assemblage type (stocked, unstocked, and fishless). Analyses were conducted using CANOCO for windows, version 4.5 (ter Braak and Smilauer 2006) for June, July, and August. Based on the length of the dominant axis from a preliminary Detrended Correspondence Analysis (DCA), a linear model (using Redundancy Analysis - RDA) was deemed appropriate (ter Braak and Smilauer 2006). To reduce the number of environmental variables entering the analyses, CANOCO ranks and chooses the variables by their importance for the microcrustacean data via forward stepwise selection $(\mathrm{p}<0.09$; ter Braak and Smilauer 2006). extent and depth of temperature-based stratification (Holmes 2012), which precluded the application of many vertical-distribution contrasts across all lakes, e.g., epi- versus hypo-

213 limnion, photic versus aphotic zone, shallow versus deep. Minimum Secchi depths across the three lake types were $1.3-2.7 \mathrm{~m}$, suggesting some impairment of the ability of visual fish 215 predators to detect zooplankton prey occurred in lakes of each type at depths of $2 \mathrm{~m}$. Despite 216 warmer temperatures within the 2-m depth zone, both stocked trout and small-bodied native 217 fishes were regularly captured there (Nasmith et al., 2010) and mesocosm experiments held trout 218 successfully within the $1 \mathrm{~m}$ depth zone (Hanisch et al., 2012). For these reasons, we limited our 219 vertical distribution contrasts across all lakes to $1 \mathrm{~m}$ versus $2 \mathrm{~m}$, i.e., within the epilimnion of all 220 study lakes. 
For the major taxonomic groups (Cladocera, Calanoida, and Cyclopoida), we determined

222 the mean relative abundance (\% of individuals) at 1 and $2 \mathrm{~m}$ for each lake; these values were

223 then used to determine means $( \pm \mathrm{SE})$ for each lake type (stocked, unstocked, and fishless).

224 Juvenile Daphnia and copepod copepodites were included with adults in these analysis. Mean

225 relative abundances (arcsine square root transformed) were analyzed using LMMs, with

226 treatment (lake type) and depth as fixed factors, and lake as a random factor.

227

228

\section{Results}

Limnology stocked lakes were a bit larger and deeper than unstocked lakes, which were, in turn, a bit deeper and larger than fishless lakes, although there was considerable overlap among lake types (Table 1). Nutrients indicated that stocked lakes were mesotrophic, while unstocked and fishless lakes were meso-eutrophic (Table 1; Carlson 1977). Lakes were stratified to various degrees by the end of July (Holmes 2012). Thermal stratification often resulted in reduced oxygen concentrations in the lower half of the water column, regardless of lake depth (Table 1).

Microcrustacean Abundance, Biomass, and Length

In total, 143,194 microcrustaceans were counted and 13,709 were measured from the 130 samples collected. Across the 14 study lakes and four sampling periods we identified 13 cladoceran, three cyclopoid and three calanoid taxa (Appendix A). among months $(\mathrm{p}<0.001, \mathrm{LMM})$. Cladoceran abundance, lowest in May and highest in July, was

244 greater in stocked compared to fishless lakes $(\mathrm{p}=0.022)$, with unstocked lakes intermediate

245 (Table 2). Calanoid abundance differed among lake types $(\mathrm{p}=0.029)$ and months $(\mathrm{p}<0.001)$, with 246 a significant interaction $(\mathrm{p}=0.042)$. Abundance was lowest in fishless lakes $(\mathrm{p}<0.03)$, but similar 247 between stocked and unstocked lakes $(\mathrm{p}>0.10)$. Abundance in fish-bearing lakes increased 
248 dramatically after May, but remained relatively low in fishless lakes (Table 2). Cyclopoid 249 abundance differed among lake types $(\mathrm{p}=0.012)$ but not months. Abundance was lowest in 250 fishless lakes ( $\mathrm{p}<0.032)$, but did not differ between stocked and unstocked lakes (Table 2).

Cladoceran taxa were largest in fishless lakes $(\mathrm{p}<0.006)$, but mean taxon length did not

252

253

254

255

256

257

258

259

260

261

262

263

264

265

266

267

268

269

270

271

272

273

274

differ between stocked and unstocked lakes, nor among months (Table 2). Calanoid taxon length differed among lake types $(p=0.034)$, but not months. Fishless lakes supported larger $(p=0.011)$ and marginally larger $(\mathrm{p}=0.056)$ calanoid taxa than stocked and unstocked lakes, respectively; the two fish-bearing lake types did not differ (Table 2). In contrast, mean lengths of cyclopoid taxa did not differ among lake types or months (Table 2).

Integrating patterns of abundance and size, cladoceran and calanoid biomass both differed among months $(p<0.001)$ but not lake types $(p>0.159)$. Cladoceran biomass was lowest in May $(\mathrm{p}<0.001)$ and marginally highest in July $(\mathrm{p}<0.089$; Table 2). Calanoid biomass was also lowest in May $(\mathrm{p}<0.001)$ and highest in July and August, which did not differ from each other $(p=0.976$, Table 2$)$. In contrast, cyclopoid biomass differed among lake types $(p=0.002)$ but not among months $(p=0.296)$. Cyclopoid biomass was lowest in fishless lakes $(p<0.015)$ and marginally lower in unstocked than in stocked lakes $(\mathrm{p}=0.066$, Table 2$)$.

\section{Microcrustacean Community Composition}

Crustacean richness differed among lake types $(\mathrm{p}<0.05)$ and months $(\mathrm{p}<0.01, \mathrm{LMM})$. Richness was greater in stocked compared to unstocked and fishless lakes $(p<0.05)$; the latter lake types did not differ ( $\mathrm{p}>0.10$; Table 2). Richness increased from May through July and then dropped in August. Only in May and July was lake area correlated with richness $(\mathrm{p}<0.05)$; correlations with depth were never significant.

No useful ordination (sensu McCune and Mefford 2011) of microcrustacean communities was created for May, most likely due to the absence of many crustacean taxa as identifiable adults. Ordination analyses of microcrustacean communities throughout the summer (JuneAugust) were similar (Holmes 2012) and best illustrated by the August ordination, which 
275 represented $92 \%$ of variance in the data set (17 taxa), at a stress level of 8.4 (Monte Carlo test, $276 p=0.003$ ). Community composition differed among lake types (MRPP; $p=0.004)$, with fishless

277 lake communities differing from both stocked $(\mathrm{p}=0.003)$ and unstocked lakes $(\mathrm{p}=0.008)$;

278 composition in the latter two lake types differed marginally ( $\mathrm{p}=0.078)$ (Fig. 1). Microcrustacean

279 taxa that were strongly correlated with the two axes $\left(\mathrm{r}^{2}>0.5\right)$ included Diaptomus leptopus, 280 Daphnia middendorffiana, and Daphnia schodleri (associated with fishless lakes), whereas

281 Skistodiaptomus oregonensis, Mesocyclops edax, and Diaphanosoma were associated with fish-

282 bearing lakes. In contrast, there was no difference in environmental factors (excluding area and 283 maximum depth) among the three lake types (MRPP; $\mathrm{p}>0.10$ ), and no environmental variables 284 were strongly correlated with the two axes $\left(r^{2}>0.3\right)$. Microcrustacean and fish communities 285 showed significant correspondence (Mantel Test; $p=0.002$ ), whereas the microcrustacean and 286 environmental matrices were not related (Mantel Test; $\mathrm{p}=0.365$ ).

The ordination of all lake-months represented $84 \%$ of variance in the data set (18 taxa), at 288 a stress level of 13.6 (Monte Carlo, p=0.003; Fig. 2). Successional vectors for stocked and 289 unstocked lakes moved in a similar upward direction from May through August, suggesting 290 increased importance of Skistodiaptomus oregonensis and Diaphanosoma, whereas vectors for 291 fishless lakes followed a perpendicular leftward trajectory through time, consistent with 292 increasing importance of Diaptomus leptopus and Daphnia middendorffiana. No environmental 293 variables were correlated $\left(r^{2}>0.3\right)$ with the ordination axes.

296 These variables explained $11-21 \%$ of the variance in microcrustacean communities, compared to 297 16- $21 \%$ explained by the fish assemblage, and $15-16 \%$ by the interaction of environment and 298 fish assemblage (Fig. 3).

Vertical Distribution 
Significant $(\mathrm{p}<0.05)$ lake type *depth interactions were detected for relative abundances

302

303

304

305

306

\section{Chaoborus Abundance and Composition}

We identified four species of Chaoborus from the study lakes (Table 1). C. americanus was exclusive to fishless lakes, C. punctipennis was exclusive to fish-bearing lakes (stocked and unstocked), C. trivitatus was found in unstocked and fishless lakes, whereas C. flavicans was common to all lake types. Chaoborus densities differed among lake types $(\mathrm{p}<0.05)$; densities were three and 14 times higher in fishless compared to unstocked and stocked lakes, respectively (Table 1).

\section{Discussion}

Overall, our comparative "natural experiment" investigating lakes in the boreal foothills of Alberta found statistically significant differences in zooplankton abundance, size, richness, community composition, and vertical distribution, and a more limited difference in biomass, among the three lake types (unstocked lakes, with native, small-bodied fish, stocked lakes, with native fishes and non-native trout, and fishless lakes). Our samples size, 56 lake-month samples across 14 lakes, was similar to other studies of fish effects on zooplankton (e.g., Donald et al. 2001, Schabetsberger and Luger 2009, Schilling et al. 2009a). Indeed, in contrast to studies based on single site-visits, our repeated-sampling design allowed us to incorporate seasonal variation in zooplankton communities (Sommer 1989).

Overall effects of lake-type, however, masked a more nuanced pattern. With the exception of taxon richness, most zooplankton metrics showed no or limited differences between stocked and unstocked lakes. In contrast, these fish-bearing lakes differed significantly from 
fishless systems in most respects, thus revealing a general fish effect, not specifically a stocked trout effect. Stable isotope signatures of dace (Chrosomus spp.), Fathead Minnow, and Brook Stickleback in our stocked and unstocked lakes indicated that zooplankton were an important dietary component (Hanisch 2016), consistent with studies on these and related species elsewhere (e.g., Naud and Magnan 1988; Hambright and Hall 1992; Laurich et al. 2003). Similarly, the positions of trout in stable isotope biplots were also consistent with a diet for which zooplankton is an important component (Hanisch 2016). Indeed, Hanisch (2016) identified microcrustaceans, especially cladocerans, as frequent and important components in the diets of trout in these systems, based on stomach-content analyses. Across 18 lake-years, representing 1055 total fish, frequency of occurrence of cladocerans averaged $52.5 \%( \pm 5.2 \mathrm{SE})$, while copepods averaged $9.0 \%( \pm 2.1 \mathrm{SE})$. Cladocerans were consistently among the top two prey items numerically and, along with chironomids, comprised collectively $20-50 \%$ of trout diets based on relative importance. The frequency and importance of planktivory was largely independent of trout size (J. Hanisch, University of Alberta, pers. comm.).

Despite the largely dichotomous pattern between microcrustacean communities (fishbearing vs. fishless lakes), limnological characteristics of lakes tended to form gradients, from stocked, to unstocked to fishless lakes (albeit with considerable overlap). The dichotomous nature of the microcrustacean communities was thus fully consistent with the well-documented effects of fish planktivory (and limited differences between predation by native fishes versus trout), but less consistent with variation in environmental factors.

\section{Microcrustacean Abundance, Biomass, and Length}

Cladocerans and calanoid copepods had greater abundances, but smaller lengths, in fishbearing compared to fishless lakes, resulting in comparable biomass among lake types. The combined planktivory of stocked trout and native fishes in stocked lakes failed to translate into additional effects on the abundance and size of major microcrustacean taxa beyond those observed in unstocked lakes generated by native fishes alone. The pattern of increased 
355

356

357

358

359

360

361

362

363

364

365

366

367

368

369

370

371

372

373

374

375

376

377

378

379

380

381

abundance but decreased size that we documented, although consistent with the outcome of trout introductions into mountain lakes lacking fish (Carlisle and Hawkins 1998), indicate that it is the presence of (zooplankton-consuming) fish, not of non-native trout per se, that are behind these community shifts. Indeed, following Hrbácek et al. (1961) and Brooks and Dodson (1965), many studies have found small microcrustaceans dominating communities in (native and/or nonnative) fish-bearing lakes, whereas various invertebrate predators (e.g., Chaoborus) and large microcrustaceans, e.g., certain Daphnia species, dominate fishless systems. Both trout and the native fishes feed selectively on large microcrustacea (Naud and Magnan 1988; Lynott et al. 1995; Laurich et al. 2003). Trout and the native fishes also feed on macroinvertebrate predators (Cochran et al. 1988; Lynott et al. 1995); in our lakes, an average of $21.1 \%$ of trout stomachs examined contained Chaoborus (J. Hanisch, unpublished data). Both of these foraging preferences should contribute to the dominance of smaller cladocerans and calanoids in fishbearing lakes (Dodson 1974; Carlisle and Hawkins 1998; Schilling et al. 2009a). In contrast, invertebrate planktivores and/or the competitive superiority of large grazing microcrustaceans can reduce or exclude smaller species in fishless systems (Brooks and Dodson 1965; Gliwicz et al. 2010).

In contrast to cladocerans and calanoids, cyclopoid copepods displayed greater mean abundance but no difference in mean length between fish-bearing (stocked and unstocked) and fishless lakes, resulting in greater cyclopoid biomass in the fish-bearing lakes. Unlike the cladoceran and calanoid species found in our study lakes, the cyclopoids (Mesocyclops edax/leukarti and Cyclops bicuspidatus thomasi) are relatively small as adults, which should reduce predation by fish (Kerfoot 1980; Ha and Hanazato 2009). In addition, cyclopoids are strong swimmers compared to cladocerans and calanoids, and thus more efficient at evading fish predation (Thorp and Covich 1991).

Beyond the lack of a size effect, fish (native or stocked) could increase cyclopoid abundance by (i) reducing the abundance of their macroinvertebrate predators, (ii) decreasing competition between cyclopoids and predatory macroinvertebrates (Liljendahl-Nurminen et al. 
382 2003), and (iii) shifting the size structure of cladocerans towards a dominance of small taxa, e.g., 383 Bosmina, which are common prey of cyclopoids (Kerfoot 1980; Ha and Hanazato 2009). An

384 abundance of smaller cladocerans in fish-bearing lakes should increase survival and reproduction 385 of adult cyclopoids (Williamson and Butler 1986; Hansen and Santer 1995; Hopp et al. 1997) 386 and developmental rates and survival of their nauplii and copepodites (Hopp and Maier 2005).

Microcrustacean Communities

Stocked lakes had richer microcrustacean communities compared to unstocked and fishless lakes. Although the larger and deeper stocked lakes might provide increased habit heterogeneity (Tessier and Welser 1991), richness was unrelated to lake depth and only marginally correlated with area, suggesting that lake morphometry contribute minimally to richness patterns across lake types. richness differences among lake types. We suggest that the greater diversity of fish predators (trout plus native fishes) in stocked lakes played a more important role.

The presence of fish could lead to greater richness through predator-mediated coexistence of species (Hairston et al. 1960). Fish feed selectively on large, often competitively superior zooplankton, which could facilitate the coexistence of competitively inferior taxa. Fish can also impact the composition and density of invertebrate predators that are capable of excluding small zooplankton (Dodson 1974). Donald et al. (2001) documented a similar increase in microcrustacean richness in lakes with both stocked trout and native fish, compared to lakes with only stocked trout and fishless lakes, suggesting that a diversity of fish species, sizes, and feeding strategies reduces dominance more effectively and allows the establishment of additional zooplankton taxa. Relative to fishless and unstocked lakes, stocked lakes also had lower densities and richness of Chaoborus, perhaps allowing some smaller, more susceptible taxa to persist (Chess et al. 1993; Schabetsberger and Luger 2009). For example, Daphnia galeata mendotae 407 and Daphnia parvula were found mostly in stocked lakes, and another small cladoceran species 408 (Ceriodaphnia lacustris) was restricted to a single stocked lake. 

summer months, as fishless and fish-bearing lakes harbored distinct microcrustacean communities, consistent with a strong fish effect in the latter (Sosnovsky and Quiros 2009;

412 Schabetsberger et al. 2009). The contrasting composition and densities of invertebrate predators, 413 including the absence of Chaoborus americanus in fish-bearing lakes, could also have 414 contributed to the dichotomy (Mackay et al. 1990). Microcrustacean communities in stocked and 415 unstocked lakes, however, differed only marginally. Although the two largest cladoceran species 416 (Daphnia middendorffiana and D. pulex) showed a strong affinity for fishless lakes, there was no 417 evidence that large cladocerans were completely extirpated after trout were introduced to naturally fish-bearing lakes, suggesting reduced effects of stocking in Alberta's boreal foothills relative to lakes at higher elevations (e.g., Schindler 2000). In addition, the largest calanoid species (Diaptomus leptopus) was exclusive to fishless lakes, while the smallest calanoid species (Skistodiaptomus oregonensis) showed a strong affinity for fish-bearing lakes (see also Donald et al. 2001).

Because of the strong relationships between fish and zooplankton, Jeppesen et al. (2011) suggested several plankton-related trophic ratios as indices of predation pressure on zooplankton. Interestingly, neither zooplankton biomass : Chl-a, Chl-a : TP nor Chl-a : TN differed among our three lake types (ANOVAs, P > 0.10; Holmes 2012 and unpublished).

Seasonal Effects on Microcrustaceans

The NMS ordinations and corresponding MRPP tests revealed similar microcrustacean communities among lake types in May, but an increasing difference between fish-bearing and

431 fishless lakes as communities developed through the summer. Indeed, differences in microcrustacean community composition (MRPP) among lake types and a relationship between fish and microcrustacean community matrices (Mantel test) were not detected in May, and the 434 percentage of variance explained by fish increased throughout the summer from June to August 435 (VPA). These results suggest that the ecological processes causing divergence among microcrustacean communities in the different lake types were weak or absent in spring but strong 
437 throughout the summer. Trout are stocked in the spring and early summer (May and June), and

438 all the native fishes in our lakes reproduce in spring, with young hatching by the end of June, to 439 begin feeding on zooplankton (Abrahams 1996). Likewise, Chaoborus americanus and $C$.

440 flavicans, two of the three species found in fishless lakes, pupate early in spring (von Ende 441 1982), suggesting that during our sampling in May, populations were dominated by early instars.

442 In contrast, densities of instar IV, to which zooplankton prey are most sensitive (Neill and 443 Peacock 1980; Elser et al. 1987), should increase over the course of the summer (von Ende 444 1982). Thus, while lake depths and areas did not change between spring (May) and summer 445 (June-August), increased planktivory by fish and Chaoborus (in fishless lakes) in June-August 446 likely contributed to the increasing community differences between fish-bearing and fishless 447 lakes seen during the summer. In contrast, the ordination trajectories of stocked and unstocked 448 lakes were essentially parallel in June, with relatively minor changes in July-August.

Vertical Distribution

Fish-bearing lakes had similar or slightly higher relative abundance and biomass of

452 Cladocera, Calanoida, and Cyclopoida at $2 \mathrm{~m}$ vs. $1 \mathrm{~m}$, whereas fishless lakes had much greater

453 amounts at $1 \mathrm{~m}$ vs. $2 \mathrm{~m}$. This pattern suggests that cladocerans (e.g., Dini and Carpenter 1992)

454 and copepods (Gliwicz and Pijanowska 1988; Doulka and Kehayias 2011) (i) occupied deeper 455 waters during the day in response to predation by fish, and/or (ii) occupied surface waters in the 456 absence of fish, potentially in response to high densities of Chaoborus and/or other

457 environmental factors (Lampert et al. 2003). In contrast, it is difficult to explain differences in 458 vertical distribution between fishless and fish-bearing lakes on the basis of depth-related 459 differences in abiotic factors.

In the absence of fish, zooplankton should occupy habitat based on factors such as 461 temperature (Gliwicz and Pijanowska 1988) and availability of phytoplankton resources 462 (Johnsen and Jakobsen 1987; Leibold 1990; Dini and Carpenter 1992). We lack data on the 463 vertical distribution of phytoplankton in our lakes, but in other moderately productive lakes, 464 phytoplankton are often abundant in warm shallow waters (Dawidowicz and Loose 1992), 
465

466

467

468

469

470

471

472

473

474

475

476

477

478

479

480

481

482

483

484

485

486

487

488

489

490

responding to greater available light (Wang et al. 2011). In addition, zooplankton growth and development benefit from higher temperatures. With a mean temperatures of $22.4 \pm 0.4{ }^{\circ} \mathrm{C}$ at $1 \mathrm{~m}$ and $20.7 \pm 0.5^{\circ} \mathrm{C}$ at $2 \mathrm{~m}$ during our study, zooplankton would have benefitted from the warmer temperature at $1 \mathrm{~m}$ (Orcutt and Porter 1983).

Chaoborus is the dominant planktivore in the pelagic zone of our fishless lakes. Several species of this non-visual predator migrate vertically to deeper waters during the day and then ascend at night in both fish-bearing (Stahl 1966; Halat and Lehman 1996) and fishless lakes (Xie et al. 1988). In fishless lakes containing migratory Chaoborus, including C. flavicans, deeper waters will not protect zooplankton from predation; as a result, zooplankton should preferentially occupy shallow waters with their warmer temperatures and higher food availability (Dodson 1988; Gonzalez 1998). Occupying shallow water in fish-bearing lakes, however, can increase susceptibility of zooplankton to predation by trout (Budy et al. 2005) and native fish (Naud and Magnan 1988; Laurich et al. 2003). Indeed, daytime distributions of zooplankton can be shaped by fish in lakes as shallow as $1.6 \mathrm{~m}$ (Castro et al. 2007). Thus, the lack of difference between stocked and unstocked lakes further supports our hypothesis that native fish "prestructure" microcrustacean communities prior to trout stocking.

\section{Fish, Chaoborus, and Microcrustacean Communities}

Frequency of occurrence, density, and species composition of Chaoborus all differed between fishless and fish-bearing lakes, with $C$. americanus exclusive to the former and $C$. punctipennis exclusive to the latter, as reported for other systems (e.g., Von Ende 1979, 1982; Yan et al. 1985; Schilling et al. 2009b). Given that Chaoborus, particularly C. americanus, can strongly affect zooplankton communities through selective feeding (Luecke and Litt 1987; Mackay et al. 1990; Liljendahl- Nurminen et al. 2003), these results reflect strong indirect impacts of fish predation. We did observe some density and minor compositional differences in Chaoborus between stocked and unstocked lakes, suggesting some additional effects of trout 
491 beyond those of native small-bodied fish, likely reflecting the increased diversity of fish in

492 stocked lakes, as discussed above (Donald et al. 2001).

493

Fish versus Environmental Differences

In contrast to the dichotomous nature of microcrustacean communities, with highly significant differences between fishless and fish-bearing lakes, but little or no difference between stocked and unstocked lakes, environmental factors differed only marginally and followed a continuous gradient across the three lake types, and overlap among lake types was extensive. The fish-bearing vs. fishless dichotomy in microcrustacean communities developed strongly only after May, consistent with the timing of trout stocking and the phenology of reproduction among native fishes. Fish also accounted for a slightly but consistently larger portion of explained variance than did the environment (VPA). Given the well-established mechanisms by which fish can affect microcrustaceans, we propose that fish were more important in structuring microcrustacean communities than environmental conditions. Similarly, Carlisle and Hawkins (1998) found that differences in environmental variables did not mediate the overriding effects of fish presence in mountain lakes in Utah.

Numerous studies have demonstrated that stocking non-native salmonids into alpine and other fishless lakes can have serious negative effects on native zooplankton, as well as other taxa

511 (e.g., Knapp et al. 2001; Dunham et al. 2004; Eby et al. 2006). Consequently, many aquatic 512 scientists view them as "a dangerous biological pollutant" (e.g., Schabetsberger et al. 2009).

513 Specifically with respect to native microcrustaceans, trout stocked into fishless lakes decrease 514 abundance and mean size, and alter the taxonomic composition and vertical distribution of the 515 community, as common, large-bodied taxa displaying at most subdued vertical migration 516 become rare or absent, and smaller taxa (either existing minor members of the community or 517 new colonists) become dominant, occupying deeper refuge layers during daytime. 

lakes, we saw the same patterns found in alpine lakes. However, these patterns were also documented for unstocked lakes containing native small-bodied fishes; indeed, for nearly all of the variables we measured, there was no difference between stocked and unstocked lakes, clearly indicating that a generic fish effect, not specifically a stocked trout effect, is largely behind the patterns observed. Our data thus add to a growing body of evidence of relatively minor effects of trout stocking on native biological communities in boreal foothills lakes (Nasmith et al. 2010, 2012; Schank et al 2011, Hanisch et al. 2012, 2013). Relative to alpine lakes, lakes within Alberta's boreal foothills may be partly buffered against trout impacts on zooplankton due to greater lake productivity, extensive macrophyte cover, and more complex native zooplankton communities. We suggest, however, that the most important factor is that boreal foothills lakes contain native small-bodied fishes, along with more complex invertebrate communities. Native fish shape the ecology and life history of invertebrate prey prior to trout introduction, resulting in communities that are not naïve to predation by fish (Jeppesen et al. 2000; Aguilera et al. 2006; Schilling et al. 2009b). fish but with native small-bodied fish can provide good candidates for trout stocking.

Understanding how stocking non-native trout influences lake ecosystems is essential for the conservation of native communities. Resource managers and aquatic scientists should not assume that trout introduction will (or will not) automatically result in strong negative effects on native biological communities (Schabetsberger et al. 2009). If stocking can be justified on broader resource management grounds, isolated lakes in Alberta's boreal foothills lacking sport

\section{Acknowledgements}

We thank Drs. R. Vinebrooke and H. Proctor for providing helpful edits and ideas. S.

543 Alberta Conservation Association provided logistical support. Thanks also to the Kutz and

544 Taylor families of Caroline, Alberta for allowing us access to their land. J. Hanisch, K. Jamali, F. 
545 Noddin, P. Pozsonyi and D. Atuke provided field and laboratory assistance. M. MacLennan 546 assisted with identification of zooplankton. Funding was provided by Alberta Conservation 547 Association, Alberta Sports, Recreation, Parks and Wildlife Foundation, Canadian Circumpolar 548 Institute, and the Natural Sciences and Engineering Research Council of Canada. 549 
550

551

552

553

554

555

556

557

558

559

560

561

562

563

564

565

566

567

568

569

570

571

572

573

574

575

576

\section{Literature Cited}

Alberta Sustainable Resource Development. Website accessed August 2012. http://www.mywildalberta.com/Fishing/documents/Fish-Stocking-Report-2009.pdf

Abrahams, M.V. 1996. Interaction between young-of-year fathead minnows and brook sticklebacks: Effects on growth and diet selection. Trans. Am. Fish. Soc. 125:480-485.

Aguilera, X., Declerck, S. and De Meester, L. 2006. Tropical high Andes lakes: a limnological survey and an assessment of exotic rainbow trout (Oncorhynchus mykiss). Limnologica $36: 258-268$.

Amsinck, S.L., Strzelczak, A., Bjerring, R., Landkildehus, F., Lauridsen, T.L., Christoffersen, K, and Jeppesen, E. 2006. Lake depth rather than fish predation determines cladoceran distribution and community structure in Faroese lakes - evidence from contemporary data and sediments. Freshwat. Biol. 51: 2124-2142.

Borcard D., Legendre, P. and Drapeau, P. 1992. Partitioning out the spatial component of ecological variation. Ecology 73:1045-1055.

Bradford, D.F., Cooper, S.D. and Jenkins, T.M. 1998. Influences of natural acidity and introduced fish on faunal assemblages in California alpine lakes. Can. J. Fish. Aquat. Sci. $55: 2478-2491$

Brooks, J.L., and Dodson, S.I. 1965. Body size, and competition of plankton. Science 150:28-35.

Budy, P., Haddix, T. and Schneldervin, R. 2005. Zooplankton size selectivity relative to gill raker spacing in rainbow trout. Trans. Am. Fish. Soc. 134:1228- 1235.

Carlisle, D.M., and Hawkins, C.P. 1998. Relationships between invertebrate assemblage structure, 2 trout species, and habitat structure in Utah mountain lakes. J. North Am. Benth. Soc. 17:286-300.

Castro, B.B., Marques, S.M., and Goncalves, F. 2007. Habitat selection and diel distribution of the crustacean zooplankton from a shallow Mediterranean lake during the turbid and clear water phases. Freshw. Biol. 52:421-433. 
577 Chess, D.W., Gibson, F., Scholz, A.T., and White, R.J. 1993. The introduction of Lahontan

578 Cutthroat Trout into a previously fishless lake: feeding habits and effects upon the

579 zooplankton and benthic community. J. Freshw. Ecol. 8:215-225.

580 Cochran P.A., Lodge, D.M., Hodgson, J.R. and Knapik, P.G. 1988. Diets of syntopic dace,

581 Phoxinus neogaeus and northern redbelly dace, Phoxinus eos: a reflection of trophic

582

583 morphology. Environ. Biol. Fishes 22:235-240.

Crutchfield, J.U., Thompson, T.E. and Swing, J.M. 2003. Ecological changes following an alewife introduction in an oligotrophic reservoir: A case history. Proc. $57^{\text {th }}$ Ann. Conf. Southeast. Assoc. Fish and Wildl. Ag. 44-58.

Culver, D.A., Boucherle, M.M., Bean, D.J. and Fletcher, J.W. 1985. Biomass of freshwater crustacean zooplankton from length-weight regressions. Can. J. Fish. Aquat. Sci. 42:13801390.

Dawidowicz P. and Loose C.J. 1992. Metabolic costs during predator-induced diel vertical migration of Daphnia. Limnol. Oceanogr. 37:1589-1595.

Dini, M.L. and Carpenter, S.R. 1992. Fish, predators, food availability and diel vertical migration in Daphnia. J. Plankt. Res. 14:359-377.

Dodson, S.I. 1974. Zooplankton competition and predation: An experimental test of the sizeefficiency hypothesis. Ecology 55:605-613.

Dodson, S.I. 1988. The ecological role of chemical stimuli for the zooplankton: Predator avoidance behavior in Daphnia. Limnol. Oceanogr. 33:1431-1439.

Donald, D.B., Vinebrooke, R.D., Anderson, R.S., Syrgiannis, J. and Graham, M.D. 2001.

Drouin, A., Sirois, P. and Archambault, P. 2009. Discriminating zooplankton communities in lakes with brook trout (Salvelinus frontinalis) and in fishless lakes. Ecoscience 16:271-281. 
604 Dunham, J.B., Pilliod, D.S. and Young, M.K. 2004. Assessing the consequences of nonnative 605 trout in headwater ecosystems in western North America. Fisheries 29:18-26.

606 Edmondson, W.T. 1959. Freshwater Biology (ed). Second edition. John Wiley and Sons, New $607 \quad$ York.

608 Elser, M.M., Von Ende, C.N., Soranno, P. and Carpenter, S.R. 1987. Chaoborus populations:

609 response of food web manipulation and potential effects on zooplankton communities. Can.

$610 \quad$ J. Zool. 65:2846-2852.

611 Gliwicz, M.Z. and Pijanowska J. 1988. Effect of predation and resource depth distribution on 612 vertical migration of zooplankton. Bull. Mar. Sci. 43:695-709.

613 Gliwicz, Z.M., Wursbaugh, W.A. and Szymanska, E. 2010. Absence of predation eliminates 614 coexistence: experience from fish-zooplankton interface. Hydrobiologia 653:103-117. 615 Gonzalez, M.J. 1998. Spatial segregation between rotifers and cladocerans mediated by 616 Chaoborus. Hydrobiologia 387/388:427-436.

617 Ha, J. and Hanazato, T. 2009. Role of interference from Daphnia and predation by cyclopoid 618 copepods in zooplankton community structure: experimental analysis using mesocosms.

Halat, K.M. and Lehman, J.T. 1996. Temperature-dependent energetic of Chaoborus Plankt. Benth. Res. 4:147-153.

Hairston, N.G., Smith, F.E. and Slobodkin, L.B. 1960. Community structure, population control, and competition. Am. Nat. 94:421-425. populations: hypothesis for anomalous distributions in the great lakes of East Africa. Hydrobiologia 330:31-36.

Hall, R.I., Leavitt, P.R., Quinlan, R. and Aruna. S. 1999. Effects of agriculture, urbanization, and climate on water quality in the Northern Great Plains. Limnol. Oceanogr. 44:739-756.

Hambright, K.D., and Hall, R.O. 1992. Differential zooplankton feeding behaviors, selectivities, and community impacts of two planktivorous fishes. Environ. Biol. Fishes 35:401-411.

Hanisch, J.R. 2016. Effects of Stocked Trout on Native Fauna of Productive Lakes. Ph.D. Thesis, Department of Biological Sciences, University of Alberta, Edmonton. 
631 Hanisch, J.R., Tonn, W.M., Paszkowski, C.A. and Scrimgeour, G.J. 2012. Complex littoral

632

633

634

635

636

637

638

639

640

641

642

643

644

645

646

647

648

649

650

651

652

653

654

655

656

habitat influences the response of native minnows to stocked trout: evidence from wholelake comparisons and experimental predator enclosures. Can. J. Fish. Aquat. Sci. 69:273281.

Hanisch, J.R., Tonn, W.M., Paszkowski, C.A. and Scrimgeour, G.J. 2013. Stocked trout have minimal effects on littoral invertebrate assemblages of productive fish-bearing lakes: a whole-lake BACI study. Freshw. Biol. 58:895-907.

Hansen, A.M., and Santer, B. 1995. The influence of food resources on the development, survival and reproduction of the two cyclopoid copepods: Cyclops vicinus and Mesocyclops leuckarti. J. Plank. Res. 17:631:646.

Hembre LK, Megard RO. 2003. Seasonal and diel patchiness of a Daphnia population: An acoustic analysis. Limnol. Oceanogr. 48:2221-2233.

Hembre, L.K., and Megard, R.O. 2005. Timing of predation by rainbow trout controls Daphnia demography and the trophic status of a Minnesota lake. Freshw. Biol. 50:1064-1080.

Herbst, D.B., Silldorff, E.L. and Cooper, S.D. 2009. The influence of introduced trout in the benthic communities of paired headwater streams in the Sierra Nevada of California. Freshw. Biol. 54:1324-1342.

Holmes, T.G. 2012. Effects of stocked trout, native small-bodied fish, and winter surface aeration on zooplankton in small Boreal Foothills lakes. M.Sc. Thesis, Department of Biological Sciences, University of Alberta, Edmonton, Alberta.

Hopp, U. and Maier, G. 2005. Survival and development of five species of cyclopoid copepods in relation to food supply: experiments with algal food in a flow-through system. Freshw. Biol. 50:1454-1463.

Hopp, U., Maier, G. and Bleher, R. 1997. Reproduction and adult longevity of five species of planktonic cyclopoid copepods reared on different diets: a comparative study. Freshw. Biol. 38:289-300. 
657 Hrbácek, J., Dvorakova, M., Korínek, V., and Prochákóva, L. 1961. Demonstration of the effect 658 of the fish stock on the species composition of zooplankton and the intensity of metabolism 659 of the whole plankton association. Verh. Int. Ver. Limnol. 14:192-195.

660

661

662

663

664

665

666

667

668

669

670

671

672

673

674

675

676

677

678

679

680

681

682

Jellyman, P.G., and McIntosh, A.R. 2010. Recruitment variation in a stream galaxiid fish: multiple influences on fry dynamics in a heterogeneous environment. Freshw. Biol. 55:19301944.

Jeppesen, E., Lauridsen, T., Mitchell, S.F. and Burns, C.W. 1997. Do planktivorous fish structure the zooplankton communities in New Zealand lakes? NZ J. Mar. Freshw. Res. 31:163-173.

Jeppesen, E., Lauridsen, T.L., Mitchell, S.F., Christoffersen, K. and Burns, C.W. 2000. Trophic structure in the pelagial of 25 shallow New Zealand lakes: changes along nutrient and fish gradients. J. Plank. Res. 22:951-968.

Johnsen G.H. and Jakobsen, P.J. 1987. The effect of food limitation on vertical migration in Daphnia longispina. Limnol. Oceanogr. 32:873-880.

Kerfoot, W.C. 1980. Evolution and ecology of zooplankton communities. University Press of New England.

Klumb, R.A., Bunch, K.L., Mills, E.L., Rudstam, L.G., Brown, G., Knauf, C., Burton, R. and Arrhenius, F. 2004. Establishment of a metalimnetic oxygen refuge for zooplankton in a productive Lake Ontario embayment. Ecol. Appl. 14:113-131.

Knapp R.A., Matthews K.R., and Sarnelle O. 2001. Resistance and resilience of alpine lake fauna to fish introductions. Ecological Monographs, 71, 401-421.

Lampert, W., McCauley, E. and Manly, B.F.J. 2003. Trade-offs in the vertical distribution of zooplankton: ideal free distribution with costs? Proc. R. Soc. Lond. 270:765- 773.

Laurich, L.M., Zimmer, K.D., Butler, M.G. and Hanson, M.A. 2003. Selectivity for zooplankton prey by fathead minnows and brook sticklebacks. Wetlands 23:416-422.

Legendre, P. and Legendre, L. 1998. Numerical ecology. Developments in environmental modeling 20. Elsevier Inc., San Diego, California, USA. 
683

684

685

686

687

688

689

690

691

692

693

694

695

696

697

698

699

700

701

702

703

704

705

706

707

Leibold, M.A. 1990. Resources and predators can affect the vertical distribution of zooplankton. Limnol. Oceanogr. 35:938-944.

Luecke, C. and Litt, A.H. 1987. Effects of predation by Chaoborus flavicans on crustacean zooplankton of Lake Lenore, Washington. Freshw. Biol. 18:185-192.

Lynott, S.T., Bryan, S.D. and Hill, T.D. 1995. Monthly and size-related changes in the diet of rainbow trout in Lake Oahe, South Dakota. J. Freshw. Ecol. 10:399-407.

Mackay, N.A., Carpenter, S.R. and Soranno, P.A. 1990. The impact of two Chaoborus species on a zooplankton community. Can. J. Zool. 68:981-985.

Martinez-Sanz, C., Garcia-Criado, F. and Fernandez-Alaez, C. 2010. Effects of introduced salmonids on macroinvertebrate communities of mountain ponds in the Iberian system of Spain. Limnetica 29:221-232.

Mathews, K.R., Pope, K.L., Preisler, H.K. and Knapp, R.A. 2001. Effects of nonnative trout on Pacific Treefrogs (Hyla regilla) in the Sierra Nevada. Copeia 2001:1130-1137.

McCauley, E. 1984. The estimation of the abundance and biomass of zooplankton in samples. In: J.A. Downing, and F.H. Rigler (eds) A manual on methods for the assessment of secondary productivity in fresh waters. Blackwell Scientific, Oxford, UK, pp 228-265.

McCune B., and Grace, J.B. 2002. Analysis of ecological communities (MjM Software Design, Glenden beach, Oregon, USA.

McCune B. and Mefford, M.J. 2011. PC-ORD. Multivariate analysis of ecological data 6. MjM Software Design, Glenden Beach, Oregon.

Nasmith, L.E., Tonn, W.M., Paszkowski, C.A. and Scrimgeour, G.J. 2010. Effects of stocked trout on native fish communities in boreal foothills lakes. Ecol. Freshw. Fish 19:279-289.

Nasmith, L.E., Tonn, W.M., Paszkowski, C.A. and Scrimgeour, G.J. 2012. Limited effects of stocked trout on littoral invertebrates in boreal foothills lakes. Can. J. Fish. Aquat. Sci. 69:178-190. 
708 709

710

711

712

713

714

715

716

717

718

719

720

721

722

723

724

725

726

727

728

729

730

731

732

733

734

Naud, M., and Magnan, P. 1988. Diel onshore migration in northern redbelly dace, Phoxinus eos (Cope), in relation to prey distribution in a small oligotrophic lake. Can. J. Zool. 66:12491253.

Orcutt Jr. J.D., and Porter, K.G. 1983. Diel vertical migration by zooplankton: constant and fluctuating temperature effects on life history parameters of Daphnia. Limnol. Oceanogr. 28:720-730.

Paine, R.T. 1966. Food web complexity and species diversity. Am. Nat. 100:65-75.

Parker, B.R., Schindler, D.W., Donald, D.B. and Anderson, R.S. 2001. The effects of stocking and removal of a nonnative salmonid on the plankton of an alpine lake. Ecosystems 4:334345.

Pink, M., Fox, M.G. and Pratt, T.C. 2007. Numerical and behavioural response of cyprinids to the introduction of predatory brook trout in two oligotrophic lakesin northern Ontario. Ecol. Freshw. Fish 16:238-249.

Pope, G.F., Carter, J.C.H. and Power, G. 1973. The influence of fish on the distribution of Chaoborus spp. (Diptera) and density of larvae in the Matamek River System, Quebec. Trans. Am. Fish. Soc. 102:707-722.

Pope K.L. 2008. Assessing changes in amphibian population dynamics following experimental manipulations of introduced fish. Cons. Biol. 22:1572-1581.

Ringelberg J., Keyser, A.L. and Flik, B.J.G. 1984. The mortality effect of ultraviolet radiation in a translucent and in a red morph of Acanthodiaptomus denticornis (Crustacea, Copepoda) and its possible ecological relevance. Hydrobiologia 112:217-222.

Schabetsberger, R., and Luger, M.S. 2009. Only the small survive: monitoring long-term changes in the zooplankton community of an alpine lake after fish introduction. Biol. Invas. $11: 1335-1345$.

Schank, C.M.M., Paszkowski, C.A., Tonn, W.M. and Scrimgeour, G.J. 2011. Stocked trout do not significantly affect wood frog populations in boreal foothills lakes. Can. J. Fish. Aquat. Sci. 68:1790-1801. 
735 Schilling, E.G., Loftin, C.S. and Huryn, A.D. 2009a. Effects of introduced fish on

736 macroinvertebrate communities in historically fishless headwater and kettle lakes. Biol.

737 Cons. 142:3030-3038.

738 Schilling, E.G., Loftin, C.S. and Huryn, A.D. 2009b. Macroinvertebrates as indicators of fish 739 absence in naturally fishless lakes. Freshw. Biol. 54:181-202.

740 Schindler, D.W. 2000. Aquatic problems caused by humans in Banff National Park, Alberta, 741 Canada. Ambio, 29:401-407.

742 Semyalo, R. and Nattabi, J.K. 2009. Diel vertical migration of zooplankton in a eutrophic bay of 743 Lake Victoria. Hydrobiologia 635,:83-394.

744 Sommer, U. 1989. Plankton ecology: succession in plankton communities. Springer, Berlin.

745 Sosnovsky, A. and Quiros, R. 2009. Effects of fish manipulation on the plankton community in small hypertrophic lakes from the Pampa Plain (Argentina). Limnologica 39:219-229.

SPSS Inc. 2010. SPSS for Mac OS X, Rel. 19.0.0. SPSS Inc., Chicago, USA.

748 749

750 751

752

753

754

755

756

757 758 759

760

761

Stahl, J.B. 1966.The ecology of Chaoborus in Myers Lake, Indiana. Limnol. Oceanogr. 11:177183.

Sullivan, M.G. 2003. Active management of walleye fisheries in Alberta: dilemmas of managing recovering fisheries. N. Am. J. Fish. Manage. 23:1343-1358.

ter Braak, C.J., and Smilauer, P. 2006. CANOCO for Windows Version 4.54. Center for Biometry Wageningen, CPRO-DLO, Wageningen, The Netherlands.

Tessier, A.J., and J. Welser. 1991. Cladoceran assemblages, seasonal succession and the importance of a hypolimnetic refuge. Freshw. Biol. 25: 85-93.

Thorp, J.H. and Covich, A.P. 1991. Ecology and classification of North American freshwater invertebrates. (Eds). Academic Press, Elsevier, Oxford, United Kingdom.

Tiberti, R., von Hardenberg, A. and Bogliani, G. 2014. Ecological impact of introduced fish in high altitude lakes: a case of study from the European Alps. Hydrobiologica 724:1-19.

Townsend, C.R. 1996. Invasion biology and ecological impacts of brown trout Salmo trutta in New Zealand. Biol. Cons. 78:13-22. 
762 Von Ende, C.N. 1979. Fish predation, interspecific predation, and the distribution of two 763 Chaoborus species. Ecology 60:119-128.

764 Wang, L., Cai, Q., Zhang, M., Xu, Y. and Kong, L. 2011. Vertical distribution of phytoplankton 765 in summer microcystis bloom period of Xiangxi Bay, Three Gorges Reservoir China. $766 \quad$ Fresenius Environ. Bull. 20:553-560.

767 Williamson, C.E. and Butler, N.M. 1986. Predation on rotifers by the suspension-feeding 768 calanoid copepod Diaptomus pallidus. Limnol. Oceanogr. 31:393-402.

769 Wissinger, S.A., McIntosh, A.R., and Greig, H.S. 2006. Impacts of introduced brown and 770 rainbow trout on benthic invertebrate communities in shallow New Zealand lakes. Freshw. 771 Biol. 51:2009-2028.

772 Xie, P., Iwakuma, T. and Fujiim, K. 1988. Studies on the biology of Chaobous flavicans 773 (Meigen) (Diptera: Chaoboridae) in a fish-free eutrophic pond, Japan. Hydrobiologia 368:8377490 .

775 Yan, N.D., Nero, R.W., Keller, W. and Lasenby, D.C. 1985. Are Chaoborus larvae more 776 abundant in acidified than in non-acidic lakes in central Canada? Holarct. Ecol. 8:93-99. 
Table 1. Summary of the fish and Chaoborus populations, as well as limnological characteristics of the 14 study lakes located in the boreal foothills of Alberta, categorized by lake type. Shown are means \pm SE (range).

\begin{tabular}{|c|c|c|c|}
\hline & & Lake type & \\
\hline Lake characteristics & Stocked $(n=6)$ & Unstocked $(\mathrm{n}=5)$ & Fishless $(\mathrm{n}=3)$ \\
\hline \multicolumn{4}{|l|}{ Fish populations } \\
\hline Trout species (no. of lakes) & $\mathrm{RN}(5), \mathrm{BN}(1), \mathrm{BK}(1)$ & - & - \\
\hline Trout stocking density (fish/ha) & $357 \pm 140(76-790)$ & - & - \\
\hline Mean Trout total length $(\mathrm{mm})^{\mathrm{a}}$ & $333 \pm 30(248-452)$ & - & - \\
\hline Native fish species (no. of lakes) & DA (6), FM (3), BS (4) & DA (5), FM (5), BS (5) & - \\
\hline Native fish densities (fish/ha) ${ }^{\mathrm{b}}$ & $5115(1288-17,766)$ & $5292(592-12,767)$ & - \\
\hline \multicolumn{4}{|l|}{ Chaoborus populations } \\
\hline Chaoborus species (no. of lakes) & $\mathrm{CF}(4), \mathrm{CP}(2)$ & CF (3), CP (2), CT (2) & $\mathrm{CF}(3), \mathrm{CT}(3), \mathrm{CA}(3)$ \\
\hline Chaoborus density (individuals/L) & $1.7 \pm 1.4(0.0-8.7)$ & $7.3 \pm 4.2(0.0-22.6)$ & $24.5 \pm 4.6(15.6-31.1)$ \\
\hline \multicolumn{4}{|l|}{ Lake Characteristics } \\
\hline Area (ha) & $17.1 \pm 4.4(3.3-31.2)$ & $11.1 \pm 2.5(5.9-17.5)$ & $4.7 \pm 2.7(1.0-10.0)$ \\
\hline Maximum depth (m) & $9.7 \pm 1.1(6.6-13.0)$ & $7.1 \pm 1.8(3.9-13.4)$ & $4.8 \pm 1.2(2.5-6.0)$ \\
\hline Surface temperature $\left({ }^{\circ} \mathrm{C}\right)$ & $17.8 \pm 0.3(17.1-18.7)$ & $18.6 \pm 0.2(17.9-19.2)$ & $19.9 \pm 0.1(19.7-20.1)$ \\
\hline Minimum dissolved oxygen (mg/L) & $3.6 \pm 0.9(1.4-6.9)$ & $2.6 \pm 0.8(0.5-4.8)$ & $2.9 \pm 0.8(1.7-4.5)$ \\
\hline Total nitrogen $(\mu \mathrm{g} / \mathrm{L})$ & $660 \pm 53(495-850)$ & $910 \pm 55(722-1018)$ & $887 \pm 159(699-1203)$ \\
\hline Total phosphorus ( $\mu \mathrm{g} / \mathrm{L})$ & $17 \pm 4(9-34)$ & $26 \pm 4(14-39)$ & $37 \pm 12(16-55)$ \\
\hline Chlorophyll-a ( $\mu \mathrm{g} / \mathrm{L})$ & $1.5 \pm 0.3(0.2-2.4)$ & $3.7 \pm 0.8(1.9-6.3)$ & $4.1 \pm 2.1(0.6-7.9)$ \\
\hline Conductivity ( $\mu \mathrm{S} / \mathrm{cm})$ & $157 \pm 32(50-265)$ & $151 \pm 32(70-230)$ & $124 \pm 75(38-272)$ \\
\hline $\mathrm{pH}$ & $7.6 \pm 0.2(6.8-7.9)$ & $7.6 \pm 0.1(7.2-7.8)$ & $7.8 \pm 0.3(7.3-8.4)$ \\
\hline Secchi depth (m) & $4.0 \pm 0.4(2.7-5.9)$ & $2.6 \pm 0.3(1.7-3.7)$ & $2.4 \pm 0.8(1.4-4.0)$ \\
\hline
\end{tabular}


Note: RN, Rainbow Trout, Oncorhynchus mykiss; BN, Brown Trout, Salmo trutta; BK, Brook Trout, Salvelinus fontinalis; DA, dace, including Pearl Dace Margariscus nachtriebi, and a species complex consisting of Northern Redbelly Dace, Chrosomus eos, Finescale Dace, Chrosomus neogaeus, and their parthenogenic hybrid; FM, Fathead Minnow, Pimephales promelas; BS, Brook Stickleback, Culaea inconstans; CF, Chaoborus flavican; CP, C. punctipennis; CT, C. trivitatus; CA, C. americanus.

åData from 2009 (J. Hanisch, University of Alberta, personal communication).

${ }^{\mathrm{b}}$ DA and FM only (Nasmith et al. 2010, 2012). 
Table 2 Mean $( \pm \mathrm{SE})$ abundance (individuals $\left.\cdot \mathrm{L}^{-1}\right)$, taxon length $(\mathrm{mm})$, and biomass $\left(\mathrm{mg} \cdot \mathrm{L}^{-1}\right)$ of major taxa and LFTL richness in each month in 2009 for each lake type: stocked lakes $(S ; n=6)$, unstocked lakes $(\mathrm{U} ; \mathrm{n}=5)$, and fishless lakes $(\mathrm{F} ; \mathrm{n}=3)$. Also presented are results from Linear Mixed Models for each taxa with lake type (LT), month (M), and their interaction (I) as main effects, and lake as a random effect. If the interaction was not significant based on preliminary analysis ( $>0.05)$, it was removed from the model.

$* 0.1>\mathrm{p}>0.05, * * \mathrm{p}<0.05$

\begin{tabular}{|c|c|c|c|c|c|c|c|c|}
\hline Taxa & $\begin{array}{l}\text { Lake } \\
\text { Type }\end{array}$ & May & June & July & August & $\begin{array}{l}\text { Mean of } \\
\text { Months }\end{array}$ & $\begin{array}{l}\text { Main } \\
\text { Effect }\end{array}$ & F-statistic \\
\hline \multicolumn{9}{|l|}{ Abundance } \\
\hline \multirow[t]{3}{*}{ Cladocera } & S & $3.7 \pm 1.8$ & $25.3 \pm 10.7$ & $63.1 \pm 10.3$ & $49.0 \pm 8.0$ & $35.3 \pm 6.2$ & $\mathrm{LT}$ & $\mathrm{F}_{2,11}=3.6^{*}$ \\
\hline & $\mathrm{U}$ & $4.8 \pm 3.0$ & $22.2 \pm 5.7$ & $35.9 \pm 13.7$ & $22.2 \pm 12.9$ & $21.3 \pm 5.2$ & $\mathrm{M}$ & $\mathrm{F}_{3,38}=23.7 * *$ \\
\hline & $\mathrm{F}$ & $0.4 \pm 0.3$ & $6.7 \pm 2.2$ & $22 . \overline{6} \pm 2.2$ & $9.1 \pm 3.0$ & $10.5 \pm 2.7$ & I & Removed \\
\hline \multirow[t]{3}{*}{ Calanoida } & S & $1.4 \pm 0.8$ & $10.5 \pm 3.1$ & $29.4 \pm 6.2$ & $22.6 \pm 6.0$ & $16.0 \pm 3.1$ & $\mathrm{LT}$ & $\mathrm{F}_{2,11}=4.9^{*}$ \\
\hline & $\mathrm{U}$ & $0.4 \pm 0.2$ & $18.8 \pm 8.0$ & $18.7 \pm 4.7$ & $35.5 \pm 13.7$ & $18.3 \pm 4.8$ & $\mathrm{M}$ & $\mathrm{F}_{3,32}=33.0 * *$ \\
\hline & $\mathrm{F}$ & $0.1 \pm 0.0$ & $1.5 \pm 1.3$ & $9.7 \pm 4.4$ & $1.9 \pm 0.5$ & $3.6 \pm 1.6$ & I & $\mathrm{F}_{6,32}=2.5 * *$ \\
\hline \multirow[t]{3}{*}{ Cyclopoida } & S & $20.7 \pm 9.2$ & $16.9+5.6$ & $27.5 \pm 7.1$ & $20.5 \pm 2.5$ & $21.4+3.2$ & $\mathrm{LT}$ & $\mathrm{F}_{2,11}=6.6^{* *}$ \\
\hline & U & $41.0 \pm 17.6$ & $14.4 \pm 9.0$ & $13.0 \pm 5.5$ & $10.3 \pm 3.3$ & $19.7 \pm 5.6$ & $\mathrm{M}$ & $\mathrm{F}_{3,38}=1.2$ \\
\hline & $\mathrm{F}$ & $3.7 \pm 3.6$ & $0.3 \pm 0.2$ & $3.9 \pm 1.6$ & $2.4 \pm 1.4$ & $2.5 \pm 0.8$ & I & Removed \\
\hline \multicolumn{9}{|l|}{ Length } \\
\hline \multirow[t]{3}{*}{ Cladocera } & $\mathrm{S}$ & $\mathrm{n} / \mathrm{a}$ & $0.82 \pm 0.05$ & $0.87 \pm 0.03$ & $0.88 \pm 0.06$ & $0.85 \pm 0.03$ & $\mathrm{LT}$ & $\mathrm{F}_{2,11}=9.5 * *$ \\
\hline & $\mathrm{U}$ & $\mathrm{n} / \mathrm{a}$ & $0.76 \pm 0.17$ & $0.77 \pm 0.14$ & $0.68 \pm 0.11$ & $0.74 \pm 0.08$ & M & $\mathrm{F}_{2,26}=0.0$ \\
\hline & $\mathrm{F}$ & $\mathrm{n} / \mathrm{a}$ & $1.25 \pm 0.04$ & $1.16 \pm 0.18$ & $1.24 \pm 0.14$ & $1.22 \pm 0.07$ & I & Removed \\
\hline \multirow[t]{3}{*}{ Calanoida } & S & $\mathrm{n} / \mathrm{a}$ & $\mathrm{n} / \mathrm{a}$ & $1.05 \pm 0.05$ & $1.05 \pm 0.02$ & $1.05 \pm 0.02$ & $\mathrm{LT}$ & $\mathrm{F}_{2,11}=4.7 * *$ \\
\hline & $\mathrm{U}$ & $\mathrm{n} / \mathrm{a}$ & $\mathrm{n} / \mathrm{a}$ & $1.09 \pm 0.08$ & $1.14 \pm 0.06$ & $1.12 \pm 0.05$ & $\mathrm{M}$ & $\mathrm{F}_{1,13}=2.8$ \\
\hline & $\mathrm{F}$ & $\mathrm{n} / \mathrm{a}$ & $\mathrm{n} / \mathrm{a}$ & $1.24 \pm 0.06$ & $1.34 \pm 0.02$ & $1.29 \pm 0.04$ & I & Removed \\
\hline \multirow[t]{3}{*}{ Cyclopoida } & S & $\mathrm{n} / \mathrm{a}$ & $\mathrm{n} / \mathrm{a}$ & $0.88 \pm 0.03$ & $0.83 \pm 0.01$ & $0.85 \pm 0.01$ & $\mathrm{LT}$ & $\mathrm{F}_{2,11}=2.2$ \\
\hline & $\mathrm{U}$ & $\mathrm{n} / \mathrm{a}$ & $\mathrm{n} / \mathrm{a}$ & $0.74 \pm 0.09$ & $0.80 \pm 0.04$ & $0.77 \pm 0.05$ & $\mathrm{M}$ & $\mathrm{F}_{1,13}=0.8$ \\
\hline & $\mathrm{F}$ & $\mathrm{n} / \mathrm{a}$ & $\mathrm{n} / \mathrm{a}$ & $0.53 \pm 0.11$ & $0.81 \pm 0.26$ & $0.67 \pm 0.14$ & I & Removed \\
\hline
\end{tabular}




\begin{tabular}{|c|c|c|c|c|c|c|c|c|}
\hline \multicolumn{9}{|l|}{ Biomass } \\
\hline \multirow[t]{3}{*}{ Cladocera } & $\mathrm{S}$ & $12.8 \pm 7.4$ & $96.2 \pm 47.9$ & $359.5 \pm 67.7$ & $286.0+51.8$ & $188.6 \pm 37.0$ & LT & $\mathrm{F}_{2,11}=1.5$ \\
\hline & $\mathrm{U}$ & $19.4 \pm 11.6$ & $121.8+42.1$ & $200.4+111.2$ & $80.5+45.3$ & $105.5+33.0$ & $\mathrm{M}$ & $\mathrm{F}_{3,38}=28.7 * *$ \\
\hline & $\mathrm{F}$ & $0.7 \pm 0.5$ & $45.9 \pm 20.6$ & $132.0 \pm 49.6$ & $78.6 \pm 7.9$ & $70.1 \pm 19.3$ & $\mathrm{I}$ & Removed \\
\hline \multirow[t]{3}{*}{ Calanoida } & $\mathrm{S}$ & $9.4 \pm 4.4$ & $47.9 \pm 15.9$ & $151.1 \pm 34.5$ & $120.9 \pm 36.0$ & $82.3 \pm 17.0$ & LT & $\mathrm{F}_{2,11}=2.2$ \\
\hline & $\mathrm{U}$ & $0.6 \pm 0.3$ & $73.0 \pm 31.5$ & $97.3 \pm 18.7$ & $197.7 \pm 79.9$ & $92.1 \pm 25.8$ & $\mathrm{M}$ & $\mathrm{F}_{3,38}=47.4 * *$ \\
\hline & $\mathrm{F}$ & $0.2 \pm 0.1$ & $25.3 \pm 22.1$ & $107 . \overline{4+81.1}$ & $32.0 \pm 7.1$ & $45.0 \pm 23.4$ & $\mathrm{I}$ & Removed \\
\hline \multirow[t]{3}{*}{ Cyclopoida } & $\mathrm{S}$ & $46.8 \pm 21.4$ & $33.8+8.6$ & $86.7 \pm 24.2$ & $69.5 \pm 14.6$ & $59.2+9.5$ & LT & $\mathrm{F}_{2,11}=11.1 * *$ \\
\hline & $\mathrm{U}$ & $42.3 \pm 17.6$ & $35.7 \pm 18.7$ & $34.9 \pm 20.4$ & $28.8 \pm 16.4$ & $35.4 \pm 8.5$ & $\mathrm{M}$ & $\mathrm{F}_{3,38}=1.3$ \\
\hline & $\mathrm{F}$ & $3.7 \pm 3.1$ & $0.4 \pm 0.2$ & $3.3 \pm 1.6$ & $3.4 \pm 1.6$ & $2.6 \pm 0.8$ & $\mathrm{I}$ & Removed \\
\hline \multicolumn{9}{|l|}{ Richness } \\
\hline & $\mathrm{S}$ & $6.0+0.3$ & $7.2+0.5$ & $9.0+0.9$ & $6.3+0.6$ & $7.1+0.4$ & LT & $\mathrm{F}_{2,11}=10.8^{* *}$ \\
\hline & $\mathrm{U}$ & $4.8+0.4$ & $6.2+1.0$ & $5.8+0.4$ & $4.4+0.2$ & $5.3+0.3$ & $\mathrm{M}$ & $\mathrm{F}_{3,38}=8.1 * *$ \\
\hline & $\mathrm{F}$ & $3.5+0.5$ & $4.3+0.3$ & $5.7+0.3$ & $5.0+1.0$ & $4.7+0.4$ & $\mathrm{I}$ & Removed \\
\hline
\end{tabular}




\section{Figure legends}

Fig. 1. Non-metric Multidimensional Scaling (NMS) joint plot of pelagic microcrustacean communities and key taxa in study lakes in August 2009. Vectors point in the direction of increased presence of key microcrustacea taxa $\left(r^{2}>0.5\right)$ and the length of vectors indicate the strength of the relationship with the ordination axes. Black triangles: stocked lakes $(n=6)$, dark grey squares: unstocked lakes $(n=5)$, light grey circles: fishless lakes $(n=3)$. None of the environmental variables examined (Table 1) were correlated $\left(r^{2}>0.3\right)$ with the axes.

Fig. 2. Non-metric Multidimensional Scaling (NMS) ordinations of pelagic microcrustacean communities in study lakes during the four monthly sampling periods (May-August) in 2009. (A) Successional vectors follow monthly centroids of each lake type through time. (B) Joint plot vectors point in the direction of increased presence of microcrustacea taxa $\left(\mathrm{r}^{2}>0.5\right)$; the length of vectors indicate the strength of the relationship with the ordination axes. None of the environmental variables examined (Table 1) were strongly correlated with the axes $\left(r^{2}>0.3\right)$. Symbols in (B) are individual lake-months: black symbols: stocked lakes; dark grey symbols: unstocked lakes; light grey symbols: fishless lakes; circles: May, squares: June, triangles: July, diamonds: August; “plus” signs: monthly centroids.

Fig. 3. Results from a two-way Variance Partitioning Analysis of effects environmental variables and fish taxa on the composition of microcrustacean communities in June, July and August, 2009. Values represent the percentage of variance in the composition of microcrustacean communities explained independently by environmental variables and fish taxa, the percentage shared by environment and fish, and the unexplained variation.

Fig. 4. Mean $( \pm \mathrm{SE})$ relative abundance of Cladocera, Calanoida, and Cyclopoida at $1 \mathrm{~m}$ (vs. 2 m) within stocked $(n=6)$, unstocked $(n=4)$, and fishless $(n=2)$ lakes. Interactions between depth and lake type were significant $(\mathrm{p}<0.05)$ for all three taxa, based on Linear Mixed-Model analyses. 
Fig. 1

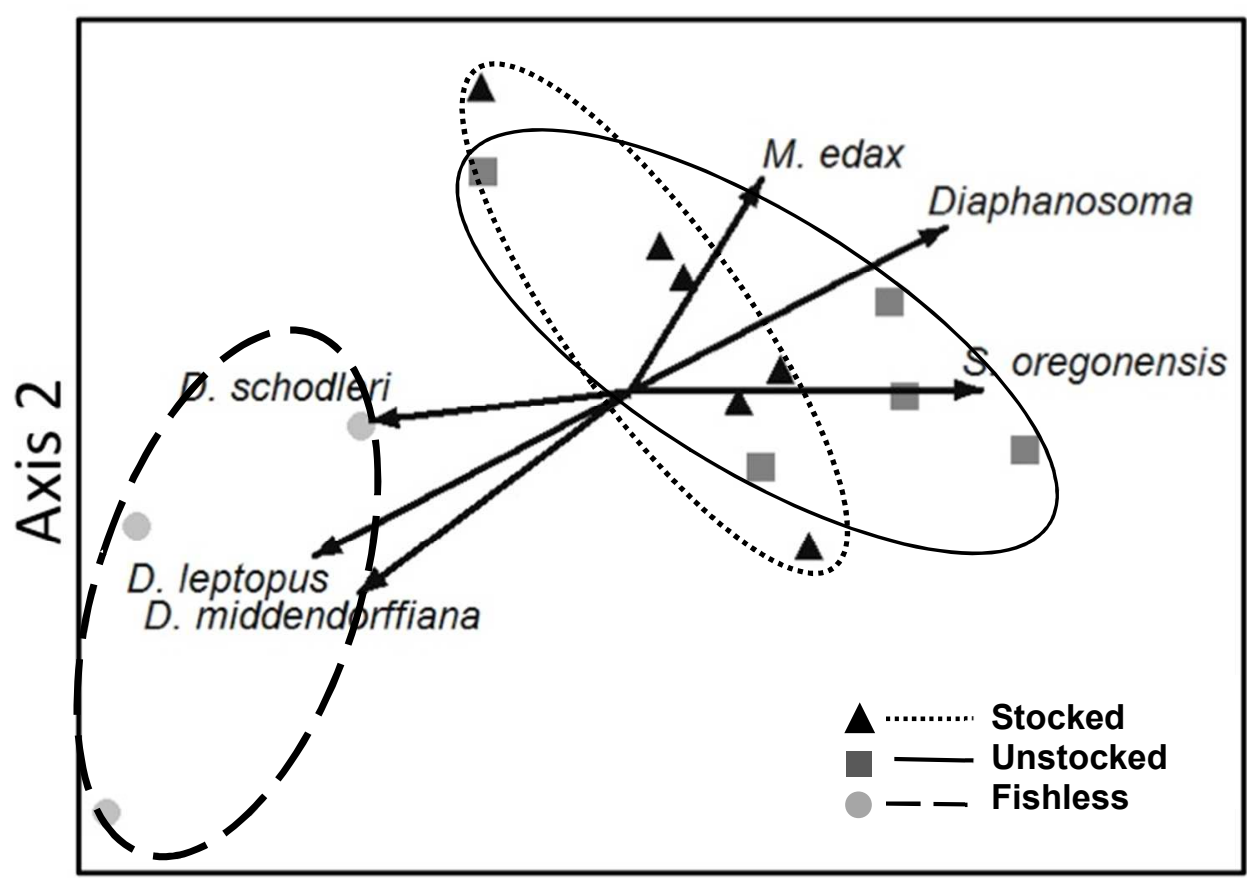

Axis 1 
Fig. 2

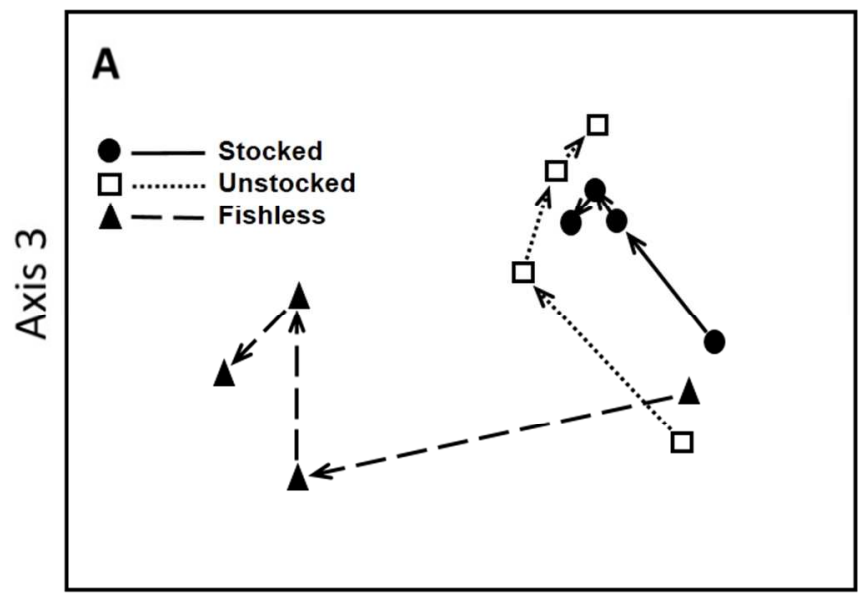

\section{Axis 1}

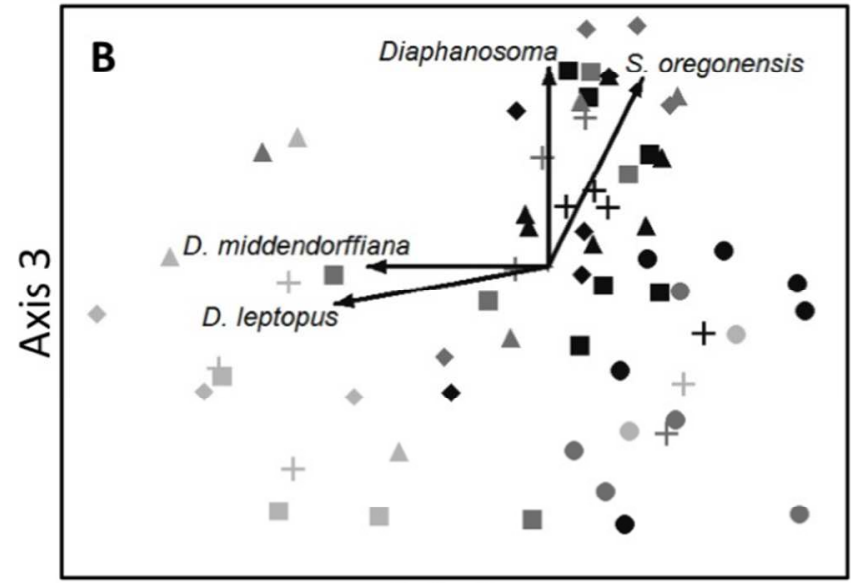

Axis 1 


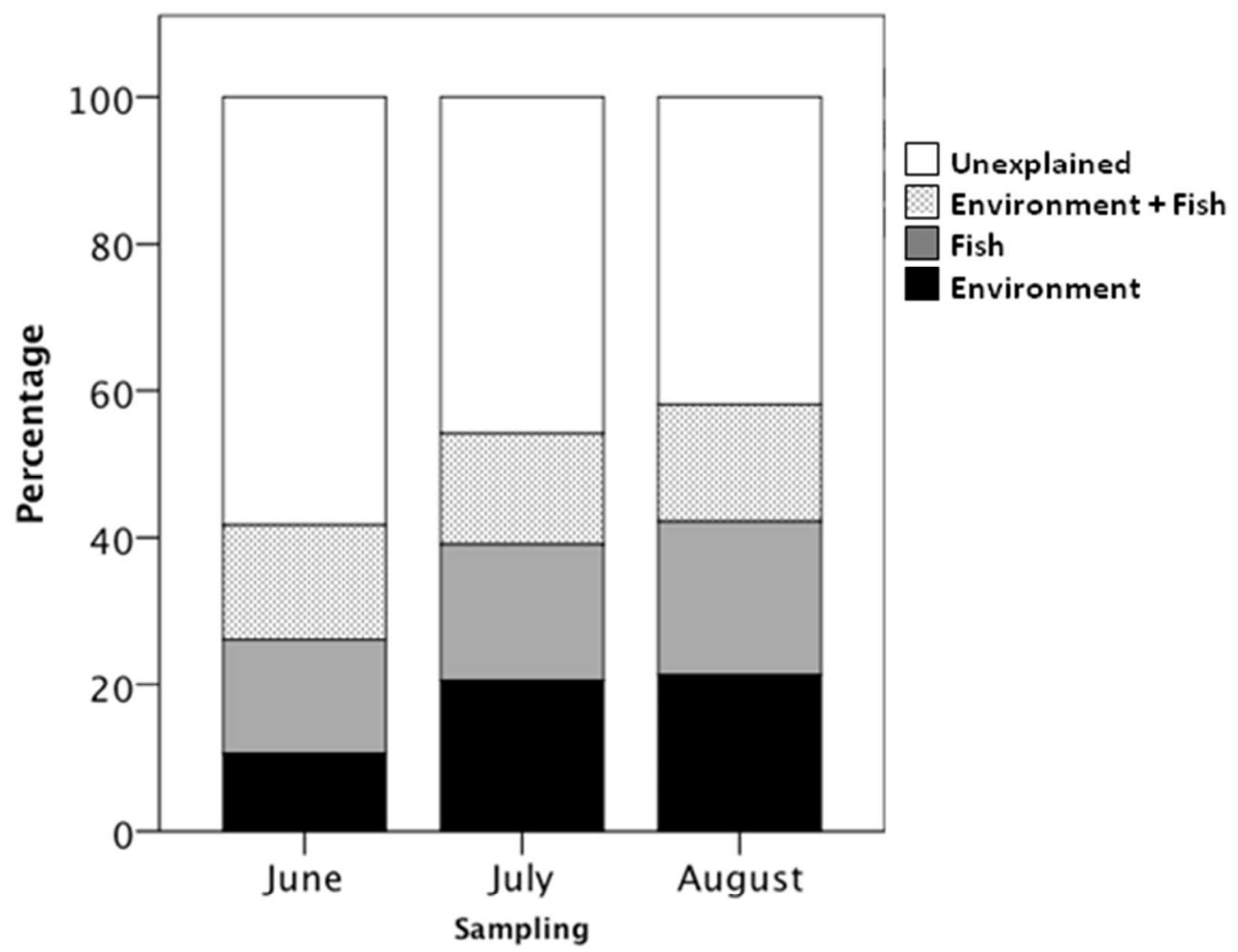

Fig. 3 

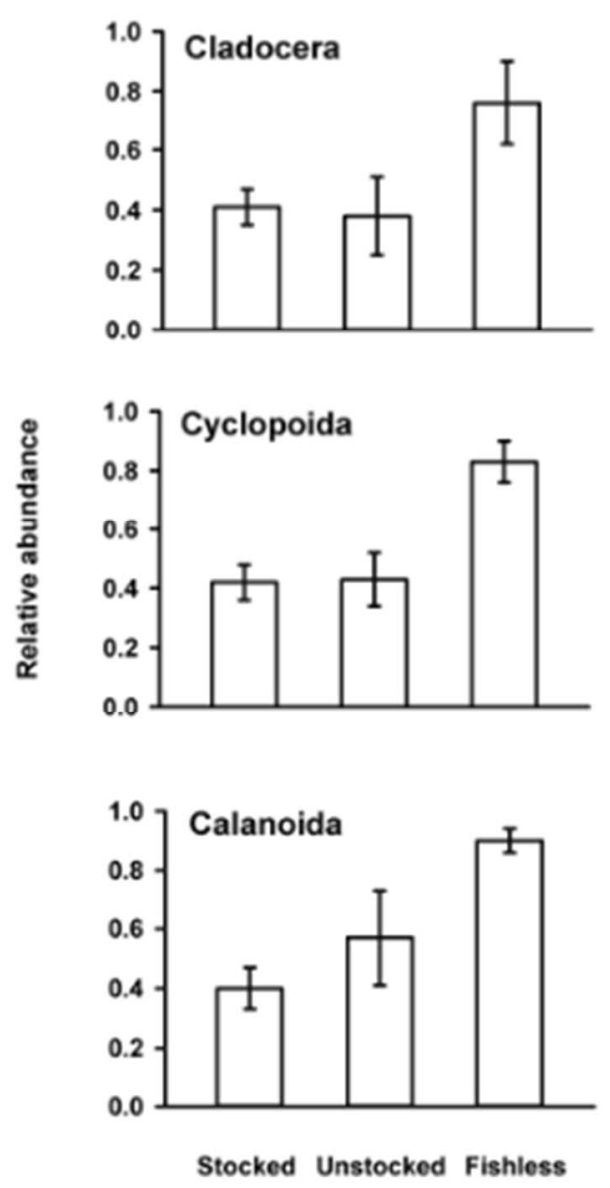

Fig. 4 


\section{Appendix A.}

Table A1. Taxa of pelagic microcrustaceans identified in the study lakes during 2009. Species listed together could not always be differentiated. Mean lengths $\pm_{\text {SE }}(\mathrm{n})$ are from all individuals measured across all lakes and months. The \% Occurrence in each lake type is based on all lake-months (May-August, except one fishless lake that was not sampled in May). S: stocked (n=24), U: unstocked $(\mathrm{n}=20)$, F: fishless $(\mathrm{n}=11)$.

\begin{tabular}{|c|c|c|c|c|c|c|c|}
\hline \multirow[t]{2}{*}{ Order } & \multirow[t]{2}{*}{ Family } & \multirow[t]{2}{*}{ Genus } & \multirow[t]{2}{*}{ Species } & \multirow{2}{*}{$\begin{array}{c}\text { Mean Length } \\
\quad \pm \text { SE (n) }\end{array}$} & \multicolumn{3}{|c|}{$\%$ Occurrence } \\
\hline & & & & & $\mathbf{S}$ & $\mathbf{U}$ & $\mathbf{F}$ \\
\hline \multirow[t]{12}{*}{ Cladocera } & Bosminidae & Bosmina & longirostris & $0.27 \pm 0.00(786)$ & 92 & 70 & 36 \\
\hline & Chydoridae & - & - & $0.26 \pm 0.00(220)$ & 42 & 55 & 27 \\
\hline & Daphniidae & Ceriodaphnia & lacustris & $0.73 \pm 0.05(7)$ & 8 & 0 & 0 \\
\hline & & Daphnia & catawba & $1.20 \pm 0.01(377)$ & 42 & 35 & 18 \\
\hline & & & galeata mendotae & $1.33 \pm 0.01(666)$ & 79 & 5 & 9 \\
\hline & & & middendorffiana & $2.36 \pm 0.05(121)$ & 4 & 15 & 45 \\
\hline & & & parvula & $0.96 \pm 0.01(118)$ & 33 & 15 & 0 \\
\hline & & & pulex & $1.69 \pm 0.02(604)$ & 42 & 40 & 64 \\
\hline & & & rosea & $1.46 \pm 0.01(317)$ & 38 & 10 & 45 \\
\hline & & & schodleri & $1.23 \pm 0.01(212)$ & 4 & 10 & 45 \\
\hline & Sididae & Diaphanosoma & brachyurum/ & $0.63 \pm 0.01(1077)$ & 67 & 65 & 18 \\
\hline & & & leuchtenbergianum & & & & \\
\hline Calanoida & Diaptomidae & Acanthodiaptomus & denticornis & $1.68 \pm 0.01(283)$ & 13 & 30 & 18 \\
\hline
\end{tabular}




\begin{tabular}{|c|c|c|c|c|c|c|c|}
\hline & & Diaptomus & leptopus & $1.95 \pm 0.03(134)$ & 0 & 0 & 82 \\
\hline \multirow{3}{*}{ Cyclopoida } & \multirow{3}{*}{ Cyclopidae } & Skistodiaptomus & oregonensis & $1.25 \pm 0.00(981)$ & 92 & 65 & 9 \\
\hline & & Cyclops & bicuspidatus thomasi & $0.98 \pm 0.00(565)$ & 79 & 35 & 18 \\
\hline & & Mesocyclops & edax/leukarti & $1.16 \pm 0.01(877)$ & 83 & 85 & 55 \\
\hline
\end{tabular}

